\title{
DNA POLYMORPHISM OF WILD SUNFLOWER ACCESSIONS HIGHIY SUSCEPTIBLE OR HIGHIY TOLERANT TO WHITE ROT ON STALK
}

\author{
Miladinović, D. ${ }^{{ }^{*}}$, Taški-Ajduković, K. ${ }^{1}$, Nagl, N. ${ }^{1}$, Kovačević, B. ${ }^{2}$, \\ Balešević-Tubić, S. ${ }^{1}$, Dušanić, N. ${ }^{1}$, Jocić, S. ${ }^{1}$
}

${ }^{1}$ Institute of Field and Vegetable Crops, Maksima Gorkog 30, 21000 Novi Sad, Republic of Serbia

${ }_{2}^{2}$ Institute of Lowland Forestry and Environment, University of Novi Sad, Antona Čehova 13, 21000 Novi Sad, Republic of Serbia

Received: November 15, 2011 Accepted: December 10, 2011

\section{SUMMARY}

DNA polymorphism in accessions of Helianthus mollis, Helianthus rigidus and Helianthus tuberosus differing in level of resistance to stem white rot caused by Sclerotinia was evaluated in reactions with two RAPD primers, C04 and $\mathrm{C} 15$, selected for their potential linkage with resistance to Sclerotinia. In total, 36 fragments using both primers were generated. All fragments generated by $\mathrm{C} 04$ were polymorphic, while 5 fragments out of 11 generated by $\mathrm{C} 15$ were monomorphic. Two major clusters were identified on the phenogram generated by UPGMA analysis, one comprising plants of $H$. mollis 1298 , and the other where all other accessions were grouped. In order to check and statistically confirm any significant association of specific fragments either with resistance or susceptibility, contingency coefficient test was done. Out of 36 fragments generated, 26 were significantly associated with resistance/susceptibility. Fragment C04-950 bp was found to be significantly associated to susceptibility, as it was generated only in susceptible accessions, while fragment C04$1200 \mathrm{bp}$ was found to be associated with the resistance, as it only occurred in $H$. mollis accessions. The selected markers should be checked and results verified in further studies including higher number of wild sunflower accessions differing in their reaction to stem white rot caused by Sclerotinia.

\section{Key words: Helianthus, Sclerotinia sclerotiorum, tolerance, RAPD}

\section{INTRODUCTION}

Sunflower (Helianthus annuus L.) is one of the most important sources of vegetable oil in the world, but the traditional breeding programs still have difficulties solving some of the problems in sunflower production, like susceptibility to dis-

* Corresponding author: Phone: +381 214898 421; Fax: +381 216413 833; e-mail: dragana.miladinovic@ifvcns.ns.ac.rs; draganavas@yahoo.com 
eases. Sclerotinia sclerotiorum (Lib.) de Bary is causing agent of white rot, one of the major sunflower diseases in humid weather conditions (Maširević and Gulya, 1992). There are no suitable cultivation or agrochemical methods for control of Sclerotinia, so the breeding for resistance is the only way to enable stable sunflower production in the area affected with this disease. Different forms of this fungus attack many plant parts: root, stem, capitulum and bud, and the reaction to the pathogen is under polygenic control. It means that plant organs can have quite different levels of resistance and express independent reactions during the infection (Robert et al., 1987; Castaño et al., 1992; Roenicke et al., 2004), so each form of attack on the plant must be considered as different disease (Mestries et al., 1996).

The complexity of the resistance mechanisms significantly complicates development of resistant sunflower hybrids and prevents development of fully tolerant or resistant genotypes (Bazzalo et al., 1991). Wild Helianthus species constitute a useful source of genes responsible for resistance to pathogens (Georgieva-Todorova, 1976), including Sclerotinia. Škorić and Rajčan (1992) and Henn et al. (1997) found the highest level of resistance to Sclerotinia stem infection in Helianthus maximiliani accessions, while Vasić et al. (2002) detected the highest level of resistance to the same infection in accessions of Helianthus mollis.

The random amplified polymorphic DNA (RAPD) (Williams et al., 1993) marker system has been used in many different applications in crops breeding and genetic research. In sunflower, RAPD markers have been used for evaluation of genetic diversity in wild species and cultivated genotypes (Vasić et al., 2003; Iqbal et al., 2010; Ribeiro, 2010), identification of progenies from interspecific crosses (Taški-Ajduković et al., 2006, Popović et al., 2008), as well as for genome mapping and tagging tolerance genes to rust (Lawson et al., 1998) and broomrape (Lu et al., 2000). They have been used in identification of white mould resistant genotypes in garlic (Nabulsi et al., 2001) and snap bean (Chung et al., 2008).

The aim of this study was to investigate DNA polymorphism in accessions of Helianthus mollis Lambert, Helianthus rigidus (Cass.) and Helianthus tuberosus L. differing in level of resistance to stem white rot caused by Sclerotinia, by using selected RAPD primers.

\section{MATERIAL AND METHODS}

Accessions of Helianthus mollis, Helianthus rigidus and Helianthus tuberosus, originating from the wild sunflower species collection of Institute of Field and Vegetable Crops, Novi Sad, Serbia, were used in the study (Table 1).

Table 1: Wild sunflower accessions used in the study and their tolerance to mid-stalk white rot

\begin{tabular}{lcccc}
\hline Accession name $^{1}$ & Genebank & Synonym & Country & Tolerance (\%) \\
\hline MOL 1298 & SRBIFVCNS & PI 468759 & USA & 100 \\
MOL X & SRBIFVCNS & - & Unknown & 100 \\
RIG 1844 & SRBIFVCNS & PI 494613 & USA & 0 \\
TUB 6 & SRBIFVCNS & - & Montenegro & 0 \\
\hline
\end{tabular}

${ }^{\top} \mathrm{MOL}-H$. mollis, RIG - H. rigidus, TUB - H. tuberosus 
The accessions were pre-screened for their tolerance to mid-stalk white rot following the protocol of Vasić et al. (2002).

DNA isolation from leaf samples of nine individual plants per accession was done following a CTAB protocol by Somma (2004). Concentration of obtained DNA was measured by visualization on $1 \%$ agarose gels in $0.5 \times \mathrm{TBE}$ buffer with ethidium bromide $(0.5 \mathrm{~g} / \mathrm{ml})$ added to the gel. The $\lambda$ phage DNA concentrations of $10 \mathrm{ng}, 20$ ng and 50 ng were used as standards. Images were taken under UV light.

The quality of the isolated DNA was evaluated by PCR reaction with universal

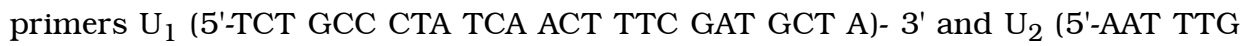
CGC GCC TGC TGC CTT CCT T-3') specific for 18S rRNK, part of the small ribosomal subunit, following the amplification program: denaturation at $95^{\circ} \mathrm{C}$ for $2 \mathrm{~min}$ followed by 35 cycles of $95^{\circ} \mathrm{C}$ for $25 \mathrm{~s}, 60^{\circ} \mathrm{C}$ for $30 \mathrm{~s}$ and $68^{\circ} \mathrm{C}$ for $45 \mathrm{~s}$, with final extension at $68^{\circ} \mathrm{C}$ for $10 \mathrm{~min}$. PCR products were separated on $2 \%$ agarose gels. Marker FastRuler ${ }^{\mathrm{TM}}$, Low Range, ready to use (Fermentas) was used as size reference.

DNA polymorphism was evaluated in reactions with two RAPD primers, C04 (5'-CCGCATCTAC-3') and C15 (5'-GACGGATCAG-3') (Sossey-Alaoui et al., 1998), selected for their potential linkage with resistance to Sclerotinia (Vasić, 2003). PCR amplification was done in $25 \mu \mathrm{l}$ reaction volume containing $2.5 \mu \mathrm{l}$ of reaction buffer (Fermentas); $1.5 \mathrm{mM} \mathrm{MgCl}_{2}, 0.2 \mathrm{mM}$ dNTP; $0.5 \mu \mathrm{M}$ primers, 2 unit Taq polymerase (Fermentas) and approx. $100 \mathrm{ng}$ DNA were used.

Amplifications were carried out in a Mastercycler ep gradient $\mathrm{S}$ termocycler (Eppendorf) with the following program: denaturation at $94^{\circ} \mathrm{C}$ for $4 \mathrm{~min}$ followed by 40 cycles of $94^{\circ} \mathrm{C}$ for $2 \mathrm{~min}, 36^{\circ} \mathrm{C}$ for $1 \mathrm{~min}$ and $72^{\circ} \mathrm{C}$ for $2 \mathrm{~min}$, with final extension at $72^{\circ} \mathrm{C}$ for $10 \mathrm{~min}$. PCR products were visualized on $1.7 \%$ agarose gel. A 50bp DNA Step ladder (Sigma) was used as size reference.

Each fragment that was amplified using RAPD primers was treated as binary unit character and scored " 0 " for absence and " 1 " for presence. An unweighted pair group arithmetic mean method (UPGMA) cluster analysis was performed, using average linkage method. Association between RAPD markers and tolerance to the Sclerotinia was measured by contingency coefficient. The statistical significance of the association was evaluated by independence test. Statistical analysis was carried out using STATISTICA 10 (StatSoft, 2011).

\section{RESULTS AND DISCUSSION}

After isolation, the DNAs were present on the gel as a high molecular weight band in all samples (Figure 1). For additional quality testing, isolated DNAs were used as template in amplifications with universal primers. In all samples the size of obtained products was $150 \mathrm{bp}$ (Figure 2) indicating that the quality of isolated DNA is suitable for RAPD-PCR analysis. The results confirmed that the CTAB protocol (Somma, 2004) is an appropriate for DNA isolation from leaves of wild Helianthus 
species, rich in polysaccharides and polyphenoles, as it enabled us to get satisfactory quantities of good quality DNA. Compared to other methods most frequently used for DNA isolation in sunflower, such as modified CTAB protocol (Permingeat et al., 1998) and method described by Gentzbittel et al. (1994), this method is rather simple and less time consuming, as it takes only 3 to 4 hours.

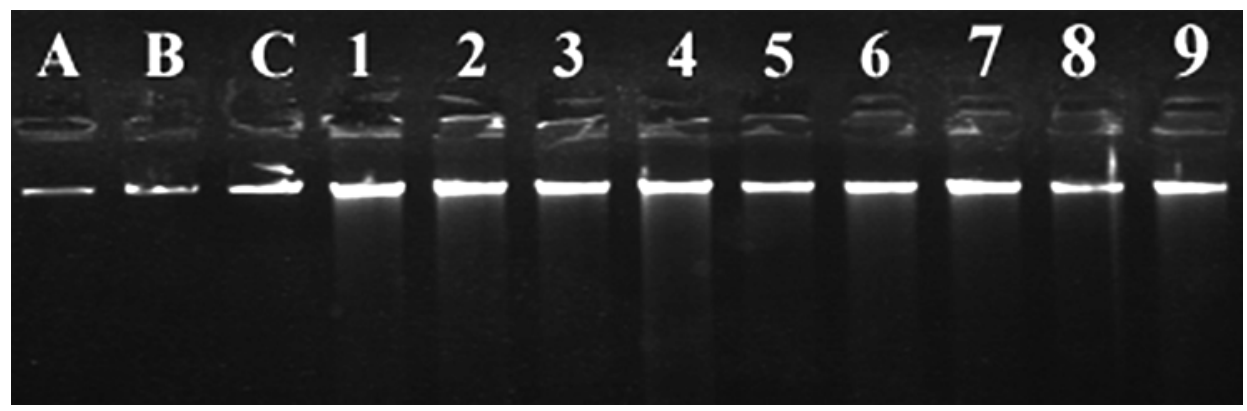

Figure 1. DNA from leaves of individual plants of accession $H$. mollis $x$ (standard DNA: A$10 \mathrm{ng}, \mathrm{B}-20 \mathrm{ng}, \mathrm{C}-50 \mathrm{ng}$ )

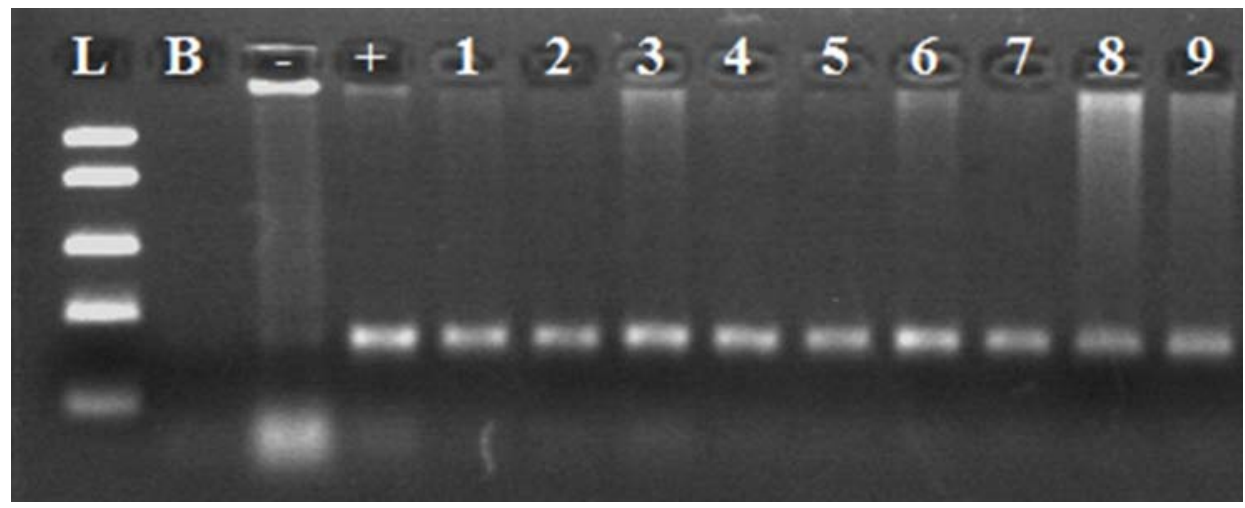

Figure 2. Agarose gel electrophoresis of PCR products obtained using the universal primers (L-DNA ladder, B-blank, - bacterial DNK, + positive control, 1-9 H. mollis $x$ )

DNA polymorphism of selected accessions, with different resistance to white rot on stalk, was analyzed by RAPD, using primers $\mathrm{CO} 4$ and $\mathrm{C} 15$. These primers were selected for their ability to amplify $H$. maximiliani 1631 fragments in somatic embryos regenerating in vitro on selective medium with oxalic acid (Vasić, 2003). It indicates that these primers are linked to the inserted $H$. maximiliani region, which might have role in regulation of Sclerotinia resistance.

In total, 36 fragments using both primers were generated. All fragments generated by $\mathrm{C} 04$ were polymorphic, while 5 fragments out of 11 generated by C15 were monomorphic.

The phenogram generated by UPGMA analysis is shown in Figure 3. Two major clusters were identified, one comprising plants of $H$. mollis 1298 , and the other 
where all other accessions were grouped. In the latter group, plants of $H$. mollis $\mathrm{x}$ formed separate sub-cluster, while plants $H$. rigidus and $H$. tuberosus were relatively similar and were grouped within the same sub-cluster. Higher variability among the plants of the same accession was observed only in $H$. mollis $\mathrm{x}$, while other accessions were rather uniform. Similar to the results obtained by other authors who used RAPD markers in wild sunflower species (Lawson et al., 1994; Sossey-Alaoui et al., 1998; Vasić et al., 2003; Ribeiro et al., 2010) our results corresponded mostly to the phylogenetic relations within the genus Helianthus. However, there was significant dissimilarity between two accessions of $H$. mollis, where accession MOL $\mathrm{X}$ was found to be more similar to accessions of plants H. rigidus and $H$. tuberosus than to the other $H$. mollis accession.
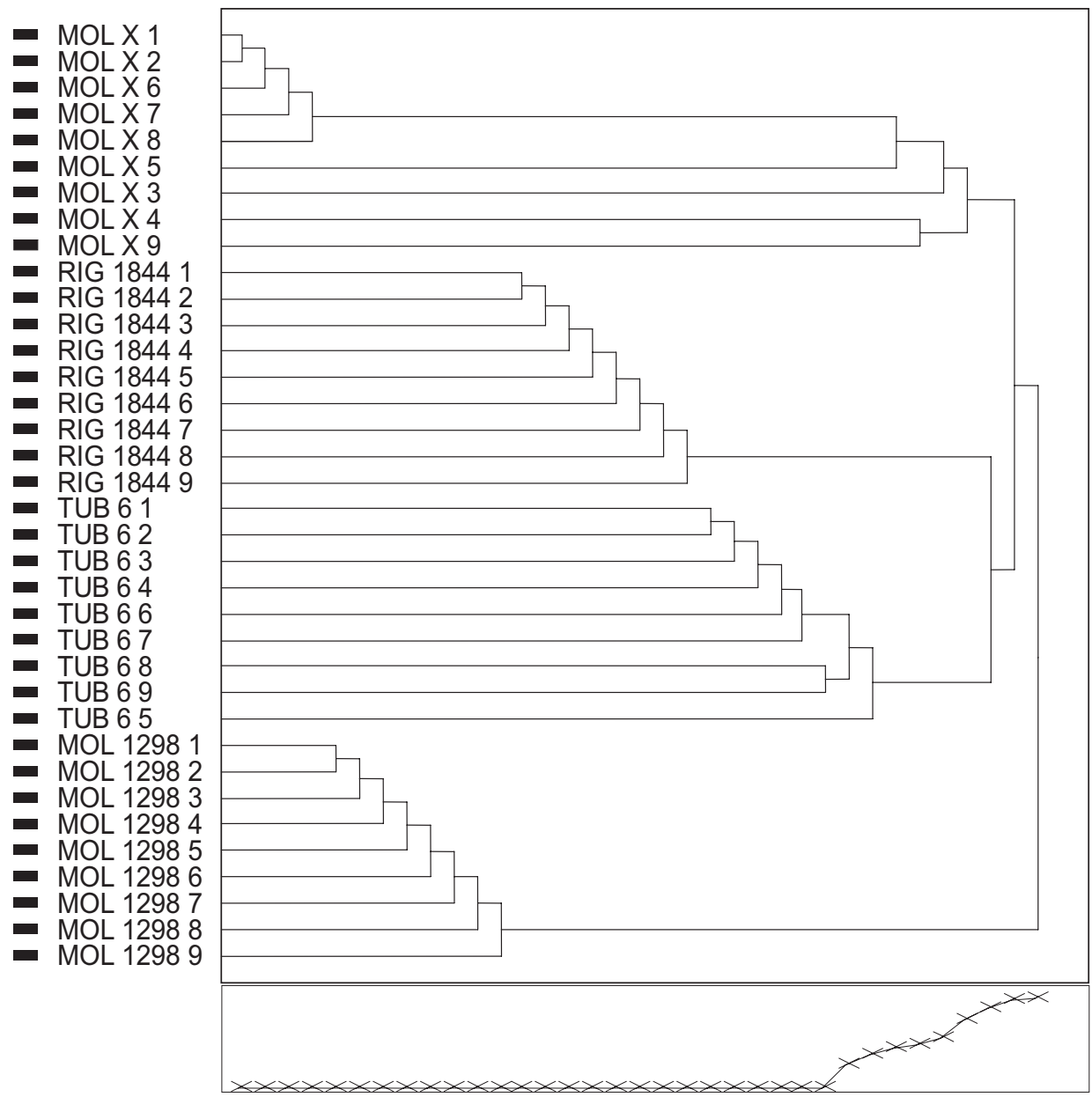

Figure 3. Dendrogram showing relationship among different accessions of tested Helianthus species based on RAPD markers using UPGMA algorithm and average distances 
After amplification with primer $\mathrm{CO} 4$ it could be detected that there was polymorphism in accession $H$. mollis $\mathrm{x}$ (Figure 4).

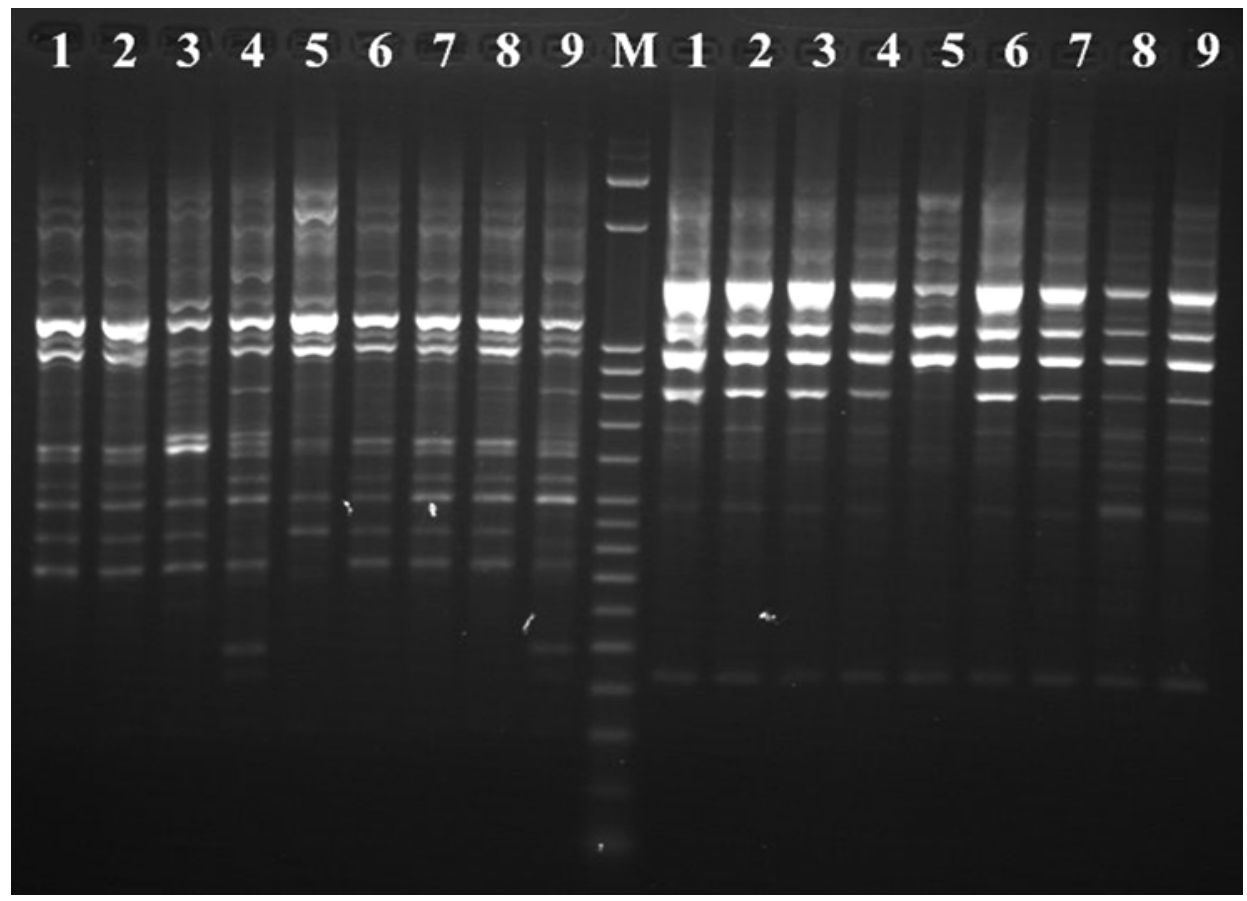

Figure 4. RAPD profile obtained with CO4 primer

(1-9 left - Helianthus mollis $x, M$ - DNA ladder; 1-9 right - Helianthus tuberosus 6)

Beside the fragments $500 \mathrm{bp}, 620 \mathrm{bp}, 1000 \mathrm{bp}, 1100 \mathrm{bp}$ and $1200 \mathrm{bp}$ that were present in all tested plants, fragments $370 \mathrm{bp}$ and $550 \mathrm{bp}$ were missing in sample no. 5 , while a fragment $600 \mathrm{bp}$ was missing in sample no. 3. Fragment $420 \mathrm{bp}$ was missing in samples 4 and 9, while fragments $220 \mathrm{bp}$ and $250 \mathrm{bp}$ occurred only in these samples. Fragment 640 bp was amplified only in samples 3 and 4 . In the accession $H$. mollis 1298 there was eight uniform fragments: $2000 \mathrm{bp}, 1500 \mathrm{bp}$, 1300 bp, 1200 bp, 900 bp, 800 bp, 670 bp and 650 bp (Figure 6). Fragment 670 bp was uniform in the accession of $H$. mollis 1298, and polymorphic in the accession $H$. mollis $\mathrm{x}$, while the fragments $1200 \mathrm{bp}$ and $650 \mathrm{bp}$ were detected in both $\mathrm{H}$. mollis accessions. The same primer in accession $H$. rigidus 1844 amplified uniform products size of $950 \mathrm{bp}, 1100 \mathrm{bp}, 1400 \mathrm{bp}, 1600 \mathrm{bp}$ and $2200 \mathrm{bp}$ (Figure 6). In accession $H$. tuberosus 6 , after amplification with primer $\mathrm{C} 04$, in all samples were found seven fragments $(220 \mathrm{bp}, 600 \mathrm{bp}, 650 \mathrm{bp}, 950 \mathrm{bp}, 1100 \mathrm{bp}, 1500 \mathrm{bp}$ and $1700 \mathrm{bp}$ ), while fragments $500 \mathrm{bp}, 550 \mathrm{bp}$ and $700 \mathrm{bp}$ were polymorphic (Figure 4).

On RAPD profile of accession $H$. mollis 1298, obtained with primer C15 all fragments $(2000 \mathrm{bp}, 1900 \mathrm{bp}, 1800 \mathrm{bp}, 1100 \mathrm{bp}, 900 \mathrm{bp}, 700 \mathrm{bp}, 500 \mathrm{bp}$ and 300 


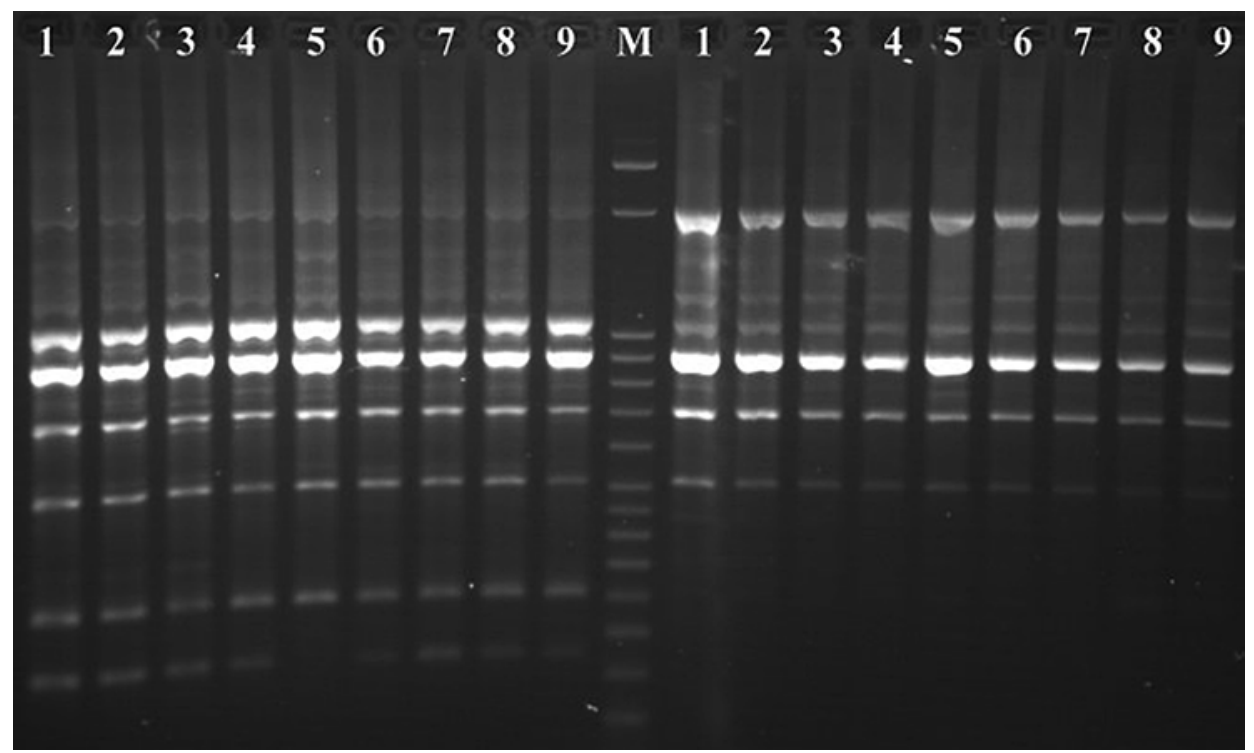

Figure 5. RAPD profile obtained with C15 primer

(1-9 left - Helianthus mollis $x, M$ - DNA ladder, 1-9 right - Helianthus tuberosus 6)

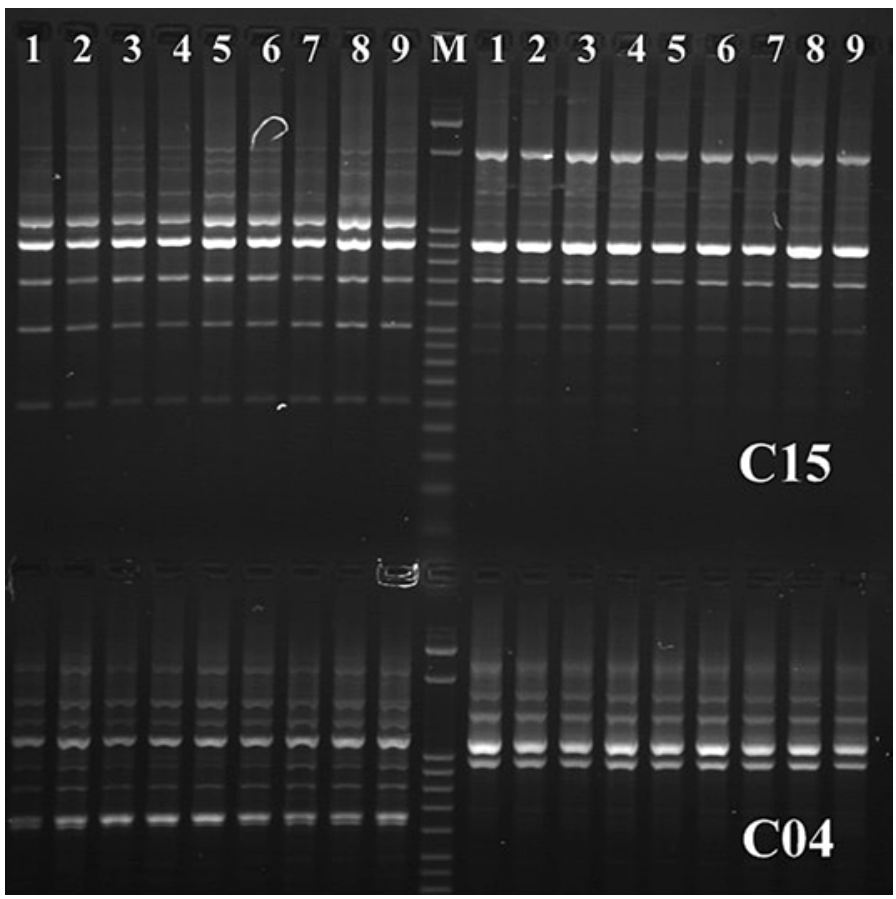

Figure 6. RAPD profile obtained with $\mathrm{C} 15$ and $\mathrm{CO} 4$ primers

(1-9 left - Helianthus mollis 1298, M - DNA ladder, 1-9 right - Helianthus rigidus 1844) 
bp) were uniform (Figure 6). The fragments of the same size as in H. mollis 1298 (2000 bp, $1100 \mathrm{bp}, 900 \mathrm{bp}, 700 \mathrm{bp}, 500 \mathrm{bp}$ and $300 \mathrm{bp}$ ) were observed on RAPD profiles of $H$. mollis $\mathrm{x}$, with the exception of the polymorphic fragment $220 \mathrm{bp}$ and fragments of very low intensity with size 1900 and $1800 \mathrm{bp}$ (Figure 5). In accession H. tuberosus 6, fragments $500 \mathrm{bp}, 700 \mathrm{bp}, 900 \mathrm{bp}, 1100 \mathrm{bp}, 1200 \mathrm{bp}$ and $2000 \mathrm{bp}$ could be detected in all samples (Figure 5). All samples of accession H. rigidus 1844 had fragments 300 bp, 420 bp, 500 bp, 700 bp, 900 bp, 1100 bp and 2000 bp (Figure 6).

Comparing the common fragments obtained in reactions with primer $\mathrm{C} 15$ in both accessions $H$. mollis with RAPD profiles of accessions $H$. tuberosus 6 and $H$. rigidus 1844, it was noticed that the 2000 bp fragment was present in all analyzed accessions, but, in $H$. tuberosus 6 and $H$. rigidus 1844 the amount of obtained PCR product was much higher than in $\mathrm{H}$. mollis. The intensity of $1100 \mathrm{bp}$ fragment, present in all examined accessions, was much lower in samples of susceptible accessions $H$. tuberosus 6 and $H$. rigidus 1844 than in both $H$. mollis accessions.

The analysis of RAPD profiles obtained in reactions with primer $\mathrm{C} 04$ showed that DNA fragments $1200 \mathrm{bp}$ and $670 \mathrm{bp}$ were present only in accessions of $\mathrm{H}$. mollis. It was also noticed that the fragment $650 \mathrm{bp}$, detected in $H$. mollis accessions, was not detected in H. rigidus 1844 and in the samples of $H$. tuberosus 6 the intensity of obtained band was very low.

Table 2: Association of loci with level of stem rot tolerance in all tested accessions expressed by contingency coefficients

\begin{tabular}{lcclcc}
\hline \multirow{2}{*}{ Loci $^{1}$} & \multicolumn{2}{c}{ Tolerance $(\%)$} & Loci $^{1}$ & \multicolumn{2}{c}{ Tolerance (\%) } \\
\cline { 2 - 5 } & 100 & 0 & & 100 & 0 \\
\hline C04-220bp & - & 0.390 & C04-1200bp & 0.707 & - \\
C04-370bp & 0.471 & - & C04-1300bp & 0.5 & - \\
C04-420bp & 0.441 & - & C04-1400bp & - & 0.5 \\
C04-550bp & 0.349 & - & C04-1600bp & - & 0.5 \\
C04-620bp & 0.5 & - & C04-1700bp & - & 0.5 \\
C04-650bp & 0.5 & - & C04-2000bp & 0.5 & - \\
C04-670bp & 0.553 & - & C04-2200bp & - & 0.5 \\
C04-700bp & - & 0.471 & C15-220bp & 0.471 & - \\
C04-800bp & 0.5 & - & C15-300bp & 0.5 & - \\
C04-900bp & 0.5 & - & C15-420bp & - & 0.5 \\
C04-950bp & - & 0.707 & C15-1200bp & & 0.5 \\
C04-1000bp & 0.5 & - & C15-1800bp & 0.5 & - \\
C04-1100bp & - & 0.5 & C15-1900bp & 0.5 & - \\
\hline
\end{tabular}

${ }^{1}$ Only loci that showed significant association with tolerance or susceptibility are presented in tabl

In order to check and statistically confirm if there was significant association of specific fragments either with resistance or susceptibility, contingency coefficient test was done (Table 2). This test was used by Hassan et al. (2011) for identifying genetic markers for Orobanche resistance in sunflower, as well as Muller et al. 
(2009) for association of traits among and within sunflower populations. Out of 36 fragments generated, 26 were significantly associated with resistance/susceptibility. As in work of El Sayed Abdel Raouf Sadek Hassan et al. (2011), contingency coefficients enabled us to single out two specific fragments that had the higher contingency coefficient values, significantly associated with either susceptibility or resistance to mid-stalk white rot. Fragment C04-950 bp was found to be significantly associated to susceptibility, as it was generated only in susceptible accessions, while fragment C04-1200 bp was found to be associated with the resistance, as it only occurred in $H$. mollis accessions.

According to the presented results, the best candidates for potential markers for resistance to Sclerotinia are fragments $1200 \mathrm{bp}$ and $670 \mathrm{bp}$, obtained in reaction with primer C04. These fragments were present in both resistant accessions of $H$. mollis, but in the accessions of $H$. rigidus 1844 and $H$. tuberosus 6 were not observed. The fragments that could also be interesting as potential markers are $2000 \mathrm{bp}$ and $1100 \mathrm{bp}$, obtained in reactions with C15 primer, as well as fragment of $650 \mathrm{bp}$, from reactions with $\mathrm{C04}$. Although these fragments were present in both resistant and susceptible accessions, the difference in the intensity of the bands was significant. The selected markers should be checked and results verified in further studies including higher number of wild sunflower accessions differing in their reaction to stem white rot caused by Sclerotinia.

\title{
ACKNOWLEDGEMENT
}

\author{
This work was supported by Ministry of Education and Science, \\ Republic of Serbia, project TR 31025.
}

\section{REFERENCES}

Bazzalo, M.E., Dimarco, P., Martinez, F. and Daleo, G.R., 1991. Indicators of resistance of sunflower plant to basal rot (Sclerotinia sclerotiorum); Symptological, biochemical, anatomical and morphological characters of the host. Euphytica 57: 195-205.

Castaño, F., Hemery-Tardin, M.C., Tourvieille de Labrouhe, D. and Vear, F., 1992. The inheritance and biochemistry of resistance to Sclerotinia sclerotiorum leaf infections in sunflower (Helianthus annuus L.). Euphytica 58: 209-219.

Chung, Y.S., Sass, M.E. and Nienhuis, J., 2008. Validation of RAPD markers for white mould resistance in two snap bean populations based on field and greenhouse evaluations. Crop Sci. 48: 2265-2273.

Hassan, E.S.A.R.S., Hoeft, E., Zenglu, Li and Tulsieram, L., 2011. Genetic markers for Orobanche resistance in sunflower. Patent No. 7872170, USPTO.

Gentzbittel, L., Zhang, G., Vear, F., Griveau, Y. and Nicolas, P., 1994. RFLP studies of genetic relationships among inbred lines of cultivated sunflower (Helianthus annuus L.): evidence for distinct restorer and maintainer germplasm pools. Theor. Appl. Genet. 89: 419425.

Georgieva-Todorova, J., 1976. Interspecific relationship in the genus Helianthus. PhD Thesis, Bulg. Acad. Sci., Sofia, Bulgaria.

Henn, H.J., Steiner, U., Wingender, R. and Schnabl, H., 1997. Wildtype sunflower clones: Source of resistance against Sclerotinia sclerotiorum (Lib.) de Bary stem infection. Angew. Bot. 71: 5-9. 
Iqbal, A., Sadaqat, H.A., Khan, A.S. and Amjad, M., 2011. Identification of sunflower (Helianthus annuus, Asteraceae) hybrids using simple-sequence repeat markers. Genet. Mol. Res. 10(1): 102-106.

Lawson, W.R., Henry, R.J., Kochman, J.K. and Kong, G.A., 1994. Genetic diversity in sunflower (Helianthus annuus L.) as revealed by random amplified polymorphic DNA analysis. Aust. J. Agric. Res. 45: 1319-1327.

Lawson, W.R., Goulter, K.C., Henry, R.J., Kong, G.A. and Kochman, J.K., 1998. Marker-assisted selection for two rust resistance genes in sunflower. Mol. Breed. 4: 227-234.

Lu, Y.H., Melero-Vara, J.M., García-Tejada, J.A. and Blanchard, P., 2000. Development of SCAR markers linked to the gene Or5 conferring resistance to broomrape (Orobanche cumana Wallr.) in sunflower. Theor. Appl. Genet. 100: 625-632.

Maširević, S. and Gulya, T.J., 1992. Sclerotinia and Phomopsis - two devastating sunflower pathogens. Field Crop Res. 30: 271-300.

Mestries, E., Gentzbittel, L., Tourvieille de Labrouhe, D., Nicolas, P. and Vear, F., 1998. Analysis of quantitative trait loci associated with resistance to Sclerotinia sclerotiorum in sunflower (Helianthus annuus L.) using molecular markers. Mol. Breed. 4: 215-226.

Muller, M.H., Delieux, F., Fernandez-Martınez, J.M., Garric, B., Lecomte, V., Anglade, G., Leflon, M., Motard, C. and Segura, R., 2009. Occurrence, distribution and distinctive morphological traits of weedy Helianthus annuus L. populations in Spain and France. Genet. Resour. Crop. Evol. 56: 869-877.

Nabulsi, I., Al-Safadi, B., Mir Ali, N. and Arabi, M.I.E., 2001. Evaluation of some garlic (Allium sativum L.) mutants resistant to white rot disease by RAPD analysis. Ann. Appl. Biol. 138: 197-202.

Popović, A., Nagl, N. and Taški-Ajduković, K., 2008. RAPD analysis of cultivated sunflower Helianthus annuus L. and its wild types. Proceedings of the International Conference Conventional and Molecular Breeding of Field and Vegetable Crops, Novi Sad, Serbia, pp. 174-176.

Permingeat, H.R., Romagnoli, M.V. and Vallejos, R.H., 1998. A simple method for isolating high yield and quality DNA from cotton (Gossypium hirsutum L.) leaves. Plant Mol. Biol. Rep. 16: $1-6$.

Ribeiro, A., Gouveia, M., Bessa, A., Ferreira, A., Magumisse, A.T., Manjate, M. and Faria, T., 2010. Population structure and genetic diversity of wild Helianthus species from Mozambique. Russ. J. Genet. 46 (8): 1086-1094.

Robert, N., Vear, F. and Tourvieille de Labrouche, D., 1987. Lheredite de la resistance au Sclerotinia sclerotiorum (Lib.) de Bary chez le tournesol. Etude des reaction a deux test mycelins. Agronomie 4: 423-429.

Roenicke, S., Hahn, V., Horn, R., Groene, I., Brahm, L., Schnabl, H. and Friedt, W., 2004. Interspecific hybrids of sunflower as a source of Sclerotinia resistance. Plant Breed. 123: 152-157.

Škorić, D. and Rajčan, I., 1992. Breeding for Sclerotinia resistance in sunflower. Proceedings of $13^{\text {th }}$ International Sunflower Conference, Pisa, Italia, pp. 1257-1262.

Somma, M., 2004. Extraction and purification of DNA. In: Querci, M., Jermini, M. and Van den Eede, G. (Eds.), The analysis of food samples for the presence of genetically modified organisms, Special Publication No. I.03.114, Session 4, European Commission DG-JRC, pp. 13-17.

Sossey-Alaoui, K., Serieys, H., Tersac, M., Lambert, P., Schilling, E., Griveau, Y., Kaan, F. and Berville, A., 1998. Evidence for several genomes in Helianthus. Theor. Appl. Genet. 97: 422-430.

Taški-Ajduković, K., Vasić, D. and Nagl, N., 2006. Regeneration of interspecific somatic hybrids between Helianthus annuus L. and Helianthus maximiliani (Schrader) via protoplast electrofusion. Plant Cell Rep. 25: 698-704.

Vasić, D., Taški, K., Terzić, S., Kevrešan, S. and Škorić, D., 2002. Transferring of Sclerotinia resistance from wild into cultivated sunflower-combining of conventional and laboratory techniques. Proc. Nat. Sci., Matica Srpska 102: 29-33.

Vasić, D., 2003. Sunflower somatic hybridization, Andrejević Endowment, Belgrade, Serbia, pp. 1-120.

Vasić, D., Miladinović, J., Berville, A. and Škorić, D., 2003. Variability of Helianthus maximiliani Schrader revealed by RAPD analysis. Plant Gen. Res. Newsletter 133: 13-15.

Williams, J.G.K., Hanafey, M.K., Rafalski, J.A. and Tingey, S.T., 1993. Genetic analysis using random amplified polymorphic DNA markers. Methods Enzymol. 218: 705-740. 